\title{
ROUTINE DETERMINATION OF MILK FAT COMPOSITION FOR NUTRITIONAL AND TECHNOLOGICAL PURPOSES
}

\author{
Eva Samková1, Oto Hanuš², Jiří Špička ${ }^{1}$, Lenka Pecová ${ }^{1}$, Jan Bedrníček ${ }^{1}$ \\ Pavel Kopunecz ${ }^{3}$, Zdeňka Klímová ${ }^{3}$, Jaroslav Kopecký ${ }^{2}$
}

\footnotetext{
${ }^{1}$ University of South Bohemia in České Budějovice, Faculty of Agricultural, Branišovská 1645/31a, 37005 České Budějovice, Czech Republic

2 Dairy Research Institute, Ltd., Prague, Ke Dvoru 12a, 16000 Praha 6-Vokovice, Czech Republic

${ }^{3}$ Czech Moravia Breeders Corporation, Benešovská 123, 25209 Hradištko, Czech Republic
}

To link to this article: https://doi.org/10.11118/actaun201967061485

Received: 26. 9. 2019, Accepted: 12.11. 2019

To cite this article: SAMKOVÁ EVA, HANUŠ OTO, ŠPIČKA JIŘÍ, PECOVÁ LENKA, BEDRNÍČEK JAN, KOPUNECZ PAVEL, KLÍMOVÁ ZDEŇKA, KOPECKÝ JAROSLAV. 2019. Routine Determination of Milk Fat Composition for Nutritional and Technological Purposes. Acta Universitatis Agriculturae et Silviculturae Mendelianae Brunensis, 67(6): 14851491.

\begin{abstract}
78 individual milk samples (IS) were taken in the Czech Fleckvieh and Holstein dairy cow herds and 33 bulk milk samples (BS) were taken in 13 Holstein dairy cow herds to compare two methods for the determination of fatty acids (FAs) - routine/indirect (infrared (IR) spectroscopy, MIR-FT) and reference/direct (gas chromatography, GC). The IS results show that the fatty acids C16:0 and C18:1 and the group of saturated (SFA) and unsaturated (UFA) FAs can be determined using routine method with a relatively high reliability (correlations (r) 0.7543, 0.7607, 0.8424 and 0.9492; $\mathrm{P}<0.001$ ). In case of polyunsaturated FAs is the $\mathrm{r}$ lower $(0.2891$; $\mathrm{P}<0.05)$. In BS the tightness of relations is stronger in the case of the SFA and UFA ( $\mathrm{r}$ 0.7094; 0.9389; P < 0.001), while for the group of TFA (trans isomers of unsaturated FAs) and PUFA (polyunsaturated FAs) are lower $\mathrm{r}(0.5897$ and 0.5931 ; $\mathrm{P}<0.001$ respectively). Routine method for fatty acids profile determination is efficient for selection of raw milk to guarantee the production of specific dairy products with increased content of healthful fatty acids.
\end{abstract}

Keywords: dairy cow, milk sample, gas chromatography, infrared spectroscopy, analytical result reliability, correlation, calibration, validation

\section{INTRODUCTION}

Results of analyses of nutrient and health indicators of milk (individual milk samples in milk recording system) are important for dairy cow breeding (genetic improvement; Klopčič et al., 2003) and control their health state (De Roos et al., 2007; Knegsel van et al., 2010; Manzenreiter et al., 2013) and reproduction parameters as non invasive monitoring. Analyses of milk quality (bulk milk samples in milk quality control system) were (GodičTorkar and Golc-Teger, 2008; Pytlewski et al., 2012) and still are (Martínez et al., 2018) very important for milk food chain safety, milk quality payment and human nutritional purposes (Aumeistere et al., 2019) and so this is essential social requirement.

Preference of certain fatty acids of milk fat in raw milk, such as unsaturated fatty acids, especially conjugated linoleic acid (CLA), is a way to promote the health benefits of dairy food. There is more ways how to purposefully modify the fatty acid profile of the milk fat (MFAP) for promoting the health of consumers or better technological properties of 
milk (Barlowska et al., 2011; Hanuš et al., 2018). Among the quickest ways there are mainly a feed ration change (Samková et al., 2011; Corazzin et al., 2019; Coppa et al., 2019) or selection of raw milk from some cows. Therefore, it is important to timely know the MFAP. The MFAP chromatographic direct (reference) determination is time-consuming and also expensive. For practical purposes, it is therefore preferable to determine some important MFAP parameters by indirect (routine) method of infrared (IR) spectroscopy (Soyeurt et al., 2006 a, b, 2011; Coppa et al., 2014) in the middle region of the IR spectrum with the Fourier transformations (MIR-FT).

The aim of this comparison was to analyze the relationship between the results of reference and routine method and indicate the possibilities of MIR-FT to MFAP determination for selection of raw milk to processing into dairy products.

\section{MATERIALS AND METHODS}

78 individual milk samples were taken in the Czech Fleckvieh and Holstein dairy cow herds and 33 bulk milk samples were taken in 13 Holstein dairy cow herds to compare two methods for the determination of fatty acids (FAs) - routine/indirect (MIR-FT) and reference/direct (gas chromatography, GC). The obtained milk samples were divided into two portions and transported immediately to the laboratory at $5{ }^{\circ} \mathrm{C}$. The first part was used for determination of selected milk quality parameters and MFAP determination by the indirect method (FT-MIR). The second part was used to determination of MFAP by the reference method (GC). No preservatives were used for all samples. The reference milk samples used had the following basic composition determined using routine analytical method (CombiFoss FT +, infrared spectroscopy), which were regularly calibrated in an accredited laboratory according to standard operating procedures by the results of the relevant reference methods:

1. individual milk samples:

- milk yield $27.2 \mathrm{~kg}$ per day,

- fat content $3.94 \pm 0.81 \%$ (variation coefficient $30.5 \%)$,

I: Characteristics of MFAP chromatography determination

\begin{tabular}{|c|c|c|}
\hline \multicolumn{2}{|c|}{ Characteristics } & Value \\
\hline \multicolumn{2}{|l|}{ Column } & SelectFAME (Varian), $60 \mathrm{~m} / 0.25 \mathrm{~mm}$ \\
\hline \multicolumn{2}{|l|}{ Detector } & FID (flame ionization) \\
\hline \multirow{3}{*}{ Temperature: } & - oven & $55^{\circ} \mathrm{C}-5 \mathrm{~min}, 40^{\circ} \mathrm{C} / \min -170^{\circ} \mathrm{C}, 2^{\circ} \mathrm{C} / \mathrm{min}-196^{\circ} \mathrm{C}, 10^{\circ} \mathrm{C} / \min -210^{\circ} \mathrm{C}-8 \mathrm{~min}$ \\
\hline & - injector & $250^{\circ} \mathrm{C}$ \\
\hline & - detector & $250^{\circ} \mathrm{C}$ \\
\hline \multicolumn{2}{|l|}{ Helium flow } & $1.8 \mathrm{ml} / \mathrm{min}$ \\
\hline \multicolumn{2}{|l|}{ Injection } & $1 \mu \mathrm{l}$, split 10 \\
\hline
\end{tabular}

- crude protein content $3.38 \pm 0.37 \%$ (20.5\%),

- lactose monohydrate content $4.94 \pm 0.24 \%$ (4.9\%);

2. bulk milk samples:

- fat content $3.98 \pm 0.52 \%$ (variation coefficient 13.2\%),

- crude protein content $3.4 \pm 0.16 \%$ (4.6\%),

- lactose monohydrate content $4.95 \pm 0.06 \%$ (1.3\%) respectively.

There were used for MFAP analysis:

- equipment CombiFoss FT + (MilkoScan FT + 76150, 79910 Fossomatic FC), 500 samples/hour. (Foss Analytical A/S, Denmark), FT-MIR method as routine/indirect method, these instruments were under regular calibrations (monthly) and proficiency testing (monthly) for basic milk composition according to relevant standard operation procedures of accredited milk recording laboratory in Buštěhrad (Czech-Moravia Breeders Corporation) and used commercial calibration of Foss for FAs determination in milk fat);

- equipment Varian 3800 (Varian Techtron, USA), GC method as reference/direct method after previous milk sample lyophilization (there is more relevant methodology information in details in Samková et al., 2018 and Tab. I), milk fat extraction with petroleum ether and conversion to methyl esters of fatty acids (by alkali catalysis).

The values of contents of the fatty acids obtained by routine method were converted to values corresponding to the expression of the reference method (in $\mathrm{g} / 100 \mathrm{~g}$ of total fatty acids) in the Microsoft Excel program. FAs and their groups were calculated as: FAs determined by the MIR-FT $(\mathrm{g} / 100 \mathrm{~g}$ in milk $) \times 100 /$ fat determined by the MIR-FT $\times$ 0.95. (FIL-IDF, 2010). There was selected menu 12.0 Statistica (StatSoft 2013) for statistical calculations (descriptive statistics, correlation and regression analysis).

\section{RESULTS AND DISCUSSION}

For the individual milk samples, there was determined lower correlation coefficient (r 0.2891; $\mathrm{P}<0.05$; Tab. II) in the case of PUFA (polyunsaturated fatty acids). Closer relationships were observed 
II: Basic statistical characteristics of selected fatty acids (FAs) and their groups in the determination by reference (gas chromatography (GC)) and routine (infrared spectroscopy (MIR-FT)) as converted to the same units of reference method (g/100 $\mathrm{g}$ of total FAs)

\begin{tabular}{|c|c|c|c|c|c|c|c|c|c|}
\hline & \multicolumn{3}{|c|}{ GC } & \multicolumn{3}{|c|}{ MIR-FT } & \multirow[b]{2}{*}{$\mathrm{r}$} & \multirow[b]{2}{*}{$\mathrm{p}$} & \multirow[b]{2}{*}{$\mathrm{R}^{2}(\%)$} \\
\hline & $\overline{\mathrm{x}}$ & $\mathrm{s}_{\mathrm{x}}$ & v (\%) & $\overline{\mathrm{x}}$ & $\mathrm{s}_{\mathrm{x}}$ & v (\%) & & & \\
\hline \multicolumn{10}{|c|}{ Individual samples $(\mathrm{n}=78)$} \\
\hline $\mathrm{C} 16: 0$ & 33.56 & 3.63 & 10.8 & 38.73 & 2.90 & 7.5 & 0.7543 & 0.001 & 56.9 \\
\hline C18:1cis-9 & 17.99 & 2.97 & 16.5 & 27.37 & 3.50 & 12.8 & 0.7607 & 0.001 & 57.9 \\
\hline SFA & 69.54 & 3.82 & 5.5 & 70.85 & 3.16 & 4.5 & 0.8424 & 0.001 & 71.0 \\
\hline UFA & 27.22 & 3.93 & 14.4 & 27.32 & 4.15 & 15.2 & 0.9492 & 0.001 & 90.1 \\
\hline PUFA & 3.26 & 0.62 & 18.9 & 8.44 & 1.38 & 16.4 & 0.2891 & 0.05 & 8.4 \\
\hline \multicolumn{10}{|c|}{ Bulk milk samples ( $\mathrm{n}=33$ ) } \\
\hline SFA & 67.65 & 2.76 & 4.08 & 72.77 & 3.77 & 5.18 & 0.7094 & 0.001 & 50.3 \\
\hline UFA & 28.80 & 2.90 & 10.08 & 27.53 & 2.52 & 9.16 & 0.9389 & 0.001 & 88.2 \\
\hline PUFA & 3.22 & 0.63 & 19.67 & 4.76 & 2.95 & 62.03 & 0.5931 & 0.001 & 35.2 \\
\hline TFA & 2.10 & 0.53 & 25.29 & 2.12 & 0.74 & 34.90 & 0.5897 & 0.001 & 34.8 \\
\hline
\end{tabular}

$\overline{\mathrm{x}}=$ arithmetic mean; $\mathrm{s}_{\mathrm{x}}=$ standard deviation; $\mathrm{v}$ in $\%=$ coefficient of variation $=\left(\mathrm{s}_{\mathrm{x}} / \overline{\mathrm{x}}\right) \times 100 ; \mathrm{r}=$ validation correlation coefficient; $\mathrm{R}^{2}$ = determination coefficient; $\mathrm{SFA}=$ saturated FAs with even and odd number of carbons; UFA = unsaturated FAs; PUFA = polyunsaturated FAs including conjugated linoleic acid; TFA = trans isomers of unsaturated FAs

III: Comparison of selected relationships (expressed by the coefficient of determination $R^{2}$ ) between fatty acids and their groups determined by routine and reference methods according to Samková et al. (2017; CM35) and by other selected authors

\begin{tabular}{lccccc}
\hline & \multirow{2}{*}{ Fatty acid } & CM35 & \multicolumn{4}{c}{ Source $^{*}$} \\
\cline { 5 - 7 } & & S2006 & C2010 & M2013 & F2014 \\
\hline C16:0 & $0.48-0.57$ & 0.89 & 0.86 & 0.93 & 0.88 \\
C18:0 & $0.30-0.45$ & 0.14 & - & 0.72 & 0.75 \\
C18:1 & $0.25-0.61$ & 0.70 & 0.86 & - & 0.96 \\
C18:2n6 (cis-9, cis-12) & - & 0.41 & - & - & 0.61 \\
C18:3n3 (all cis-9, 12, 15) & - & 0.27 & 0.15 & - & 0.87 \\
C18:2 (cis-9, trans-11; CLA) & - & 0.80 & 0.59 & - & 0.78 \\
SFA & $0.51-0.74$ & 0.77 & 0.91 & 0.99 & 0.98 \\
MUFA & $0.27-0.57$ & 0.69 & 0.89 & - & 0.97 \\
PUFA & $0.08-0.41$ & 0.22 & 0.65 & - & 0.59 \\
TFA & $0.03-0.33$ & - & 0.5 & - & 0.80 \\
SCFA & $0.11-0.37$ & - & - & 0.95 & - \\
MCFA & $0.05-0.14$ & - & - & 0.96 & - \\
\hline
\end{tabular}

"S2006 = Soyeurt et al., 2006a: FAs were expressed in g/100 g of fat; C2010 = Coppa et al., 2010: FAs were determined by NIRS method (near-infrared reflectance spetroscopy) and expressed in g/100 g of FAs; M2013 = Maurice-Van Eijndhoven et al., 2013: g/dl of milk; F2014 = Ferrand-Calmels et al., 2014: g/100 g of FAs; $\mathrm{R}^{2}$ = coefficient of determination (square of correlation coefficient $r_{x y}$ ); CLA = conjugated linoleic acid; SFA = group of saturated fatty acids; MUFA = group of monounsaturated fatty acids; PUFA = group of polyunsaturated fatty acids; TFA = group of trans isomers of UFA; SCFA = group of short chain fatty acids; MCFA = group of medium chain fatty acids.

in groups of SFA (saturated fatty acids; $r$ 0.8424; $\mathrm{P}<0.001$ ) and UFA (unsaturated fatty acids; $\mathrm{r}$ 0.9492; $\mathrm{P}<0.001$ ). Both of these groups could be determined using the routine method with a higher degree of reliability. This means that 71 and $90.1 \%$ of the variability in the SFA and UFA values determined by routine method (MIR-FT) is explainable due to variations in analyzes of reference method (GC). This mentioned fact can be described as good ability to analytical results of indirect method. It this way there was achieved acceptable result reliability to the practical interpretation. Also in the case of $\mathrm{C} 16: 0$ 

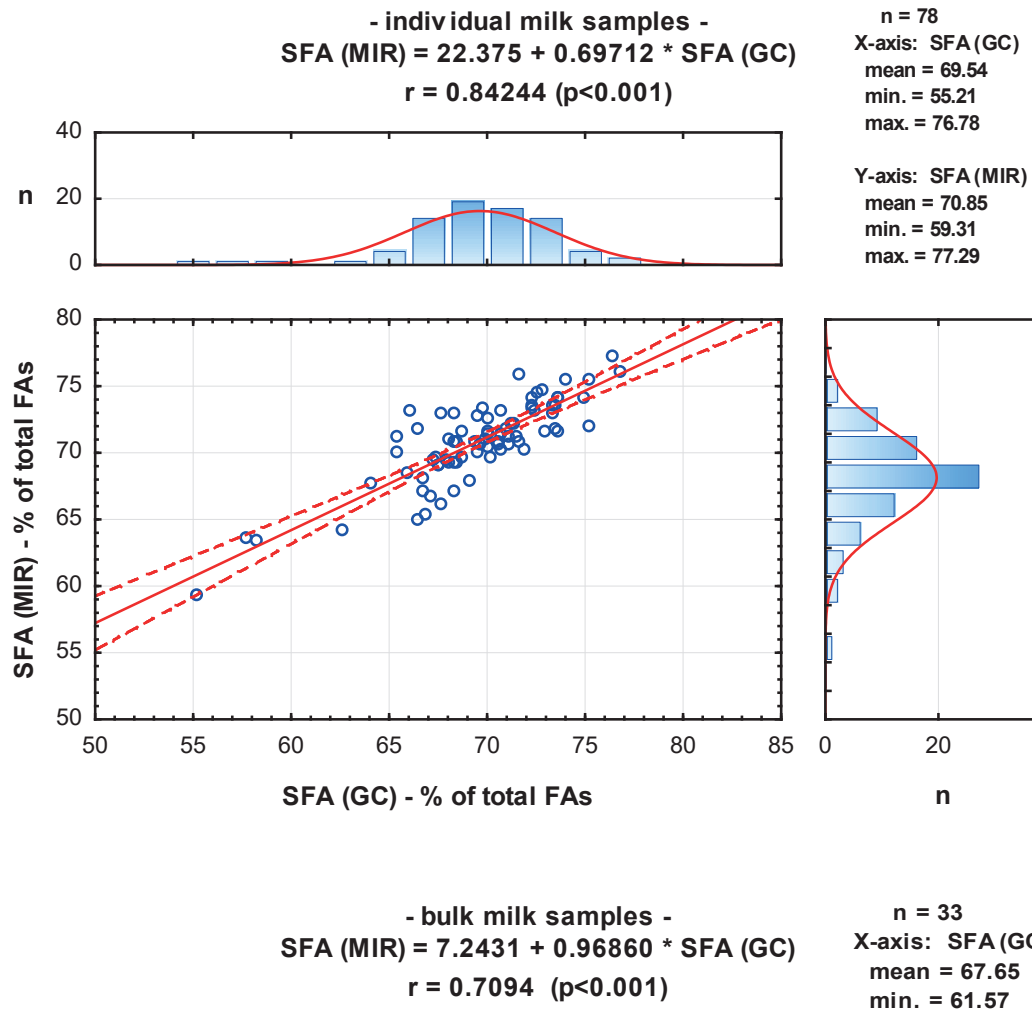

$n=33$

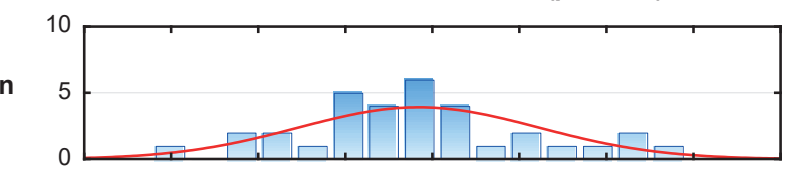

$X$-axis: $\operatorname{SFA}(\mathrm{GC})$

mean $=67.65$

$\min .=61.57$

$\max .=73.85$

Y-axis: SFA (MIR)

mean $=72.77$

$\min .=62.18$

$\max .=79.11$
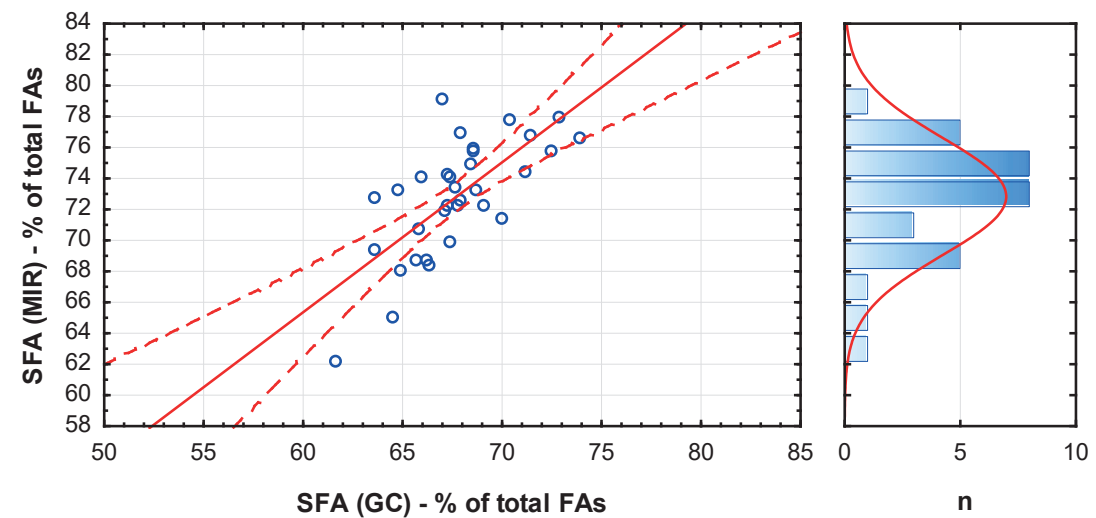

1: Relationship between proportion of saturated fatty acids (SFA) in milk fat determinated by reference (gas chromatography (GC)) and routine (infrared spectroscopy (MIR-FT))

and $\mathrm{C} 18: 1$ there were the validation correlation coefficients statistically highly significant (r 0.7543 respectively $0.7607 ; \mathrm{P}<0.001$ ). In these cases, 56.9 and $57.9 \%$ of variation in the $\mathrm{C} 16: 0$ and $\mathrm{C} 18: 1$ values determined by routine method is explainable by variation in the reference method values. From methodology point of view it is still possible to identify this fact as acceptable result reliability in terms of practical use.

For bulk milk samples there were found higher tightness of the relationship between the results in groups of SFA ( $\mathrm{r}$ 0.7094; $\mathrm{P}<0.001$ ) and UFA (r 0.9389; $\mathrm{P}<0.001 ;$ Tab. II). These values show that 50.3 and $88.2 \%$ of the variability in the SFA and UFA values determined by routine method is explainable by variations in the analysis by reference method. The mentioned facts can be described as reasonable and good analytical ability of indirect method. Even the results of relations with less determination coefficients (PUFA and TFA (trans isomers of unsaturated fatty acids)), where only 35.2 and $34.8 \%$ of variation of MIR-FT results is explainable by reference result variation, are interesting and could be practically reflected in the possible 
selection methodology of raw milk for specific dairy production for instance it means for functional foods or more spreadable butter in the position of orientation or complementary indicators. Groups of fatty acids or fatty acids with higher methodological determination coefficients $\left(\mathrm{R}^{2}\right)$ of results would then be taken into account in this process in the position of the main indicators.

In most cases, the correlations of results between methods are higher for individual than the bulk milk samples (Fig. 1). This is probably due to the higher initial variability and larger variation range of the original values of individual fatty acids in individual milk samples as compared to bulk samples which is logical. This phenomenon is generally included in all calibration files for the routine methods (other than the infrared spectroscopy as well) for all components and properties of milk (Sojková et al., 2009; Hanuš et al., 2014). In general, it is caused and also limited essentially by the randomness of choice of relevant milk samples. Most of these validation correlations (Tab. II) between results of observed methods was in similar values (with respect to relationship tightness and monitored fatty acid or group of fatty acids) as compared to previously published results (Soyeurt et al., 2006a, 2011). There is also included a comparison of relationships between results of reference and routine methods at MFAP determination in Tab. III. The results of presented papers (Tab. III) are in good accordance with results presented in this work. For instance, regarding the coefficients of determination between the types of analyzes (routine and reference) for SFA and PUFA, literary fields (Tab. III; without results Samková et al., 2017; M35) 0.77-0.99 and 0.22-0.65 are approximately comparable to our results in individual and bulk milk samples 0.71 and 0.5 and 0.08 and 0.35 (Tab. II), which are a little bit lower.

In the case of prediction of MFAP in bulk milk samples on the basis of information on farm practices (especially the composition of the cow diet and altitude) there were good $\left(\mathrm{R}^{2}>0.5\right)$ prediction models for example for the SFA or PUFA and very good $\left(\mathrm{R}^{2}>0.6\right)$ for TFA. Also the estimate of MFAP by routine (MIR-FT) method is useful predictive model for the SFA or MUFA. Within this context it was reported by Coppa et al. (2013) and Soyeurt et al. (2006a). These models could provide valuable means to farmers for improvement of the nutritional quality of milk produced by them.

\section{CONCLUSION}

Routine method for MFAP determination in cows is enough efficient for any screening and selection of raw milk to guarantee the production of specific dairy products with increased content of healthful fatty acids.

List of abbreviations: BS bulk milk sample; FAs fatty acids; CLA conjugated linoleic acid; GC gas chromatography; IR infrared spectroscopy (MIR-FT infrared spectroscopy in mid area with Fourier transformation); IS individual milk sample; MCFA group of medium chain fatty acids; MFAP milk fatty acid profile; MUFA group of monounsaturated fatty acids; NIRS near-infrared reflectance spetroscopy method; PUFA group of polyunsaturated fatty acids; SCFA group of short chain fatty acids; SFA group of saturated fatty acids; TFA group of trans isomers of UFA; UFA group of unsaturated fatty acids.

\section{Acknowledgements}

This paper was supported by projects MZe QK1910174, RO1419 and GAJU 028/2019/Z. Further the authors thank Mr. director Ass. Prof. Dipl. Eng. Josef Kučera, Mr. Dipl. Eng. Jan Zlatníček and Mr. Zdeněk Motyčka from ČMSCH a.s. for their professional and technical cooperation.

\section{REFERENCES}

AUMEISTERE, L., CIPROVIČA, I., ZAVADSKA, D., ANDERSONS, J., VOLKOVS, V. and CELMALNIECE, K. 2019. Impact of maternal diet on human milk composition among lactating women in Latvia. Medicina, 55(5): E173.

BARLOWSKA, J., SZWAJKOWSKA, M., LITWIŃCZUK, Z. and KRÓL, J. 2011. Nutritional value and technological suitability of milk from various animal species used for dairy production. Comprehensive Reviews in Food Science and Food Safety, 10(6): 291-302.

COPPA, M., FERlAY, A., CHASSAING, C., AGABRIEL, C., GLASSER, F., CHILliARD, Y., BORREANI, G., BARCAROLO, R., BAARS, T., KUSCHE, D., HARSTAD, O. M., VERBIČ, J., GOLECKÝ, J. and MARTIN, B. 2013. Prediction of bulk milk fatty acid composition based on farming practices collected through on-farm surveys. Journal of Dairy Science, 96(7): 4179-4211.

COPPA, M., FERLAY, A., LEROUX, C., JESTIN, M., CHILLIARD, Y., MARTIN, B. and ANDUEZA, D. 2010. Prediction of milk fatty acid composition by near infrared reflectance spectroscopy. International Dairy Journal, 20(3): 182-189. 
COPPA, M., CHASSAING, C., SIBRA, C., CORNU, A., VERBIČ, J., GOLECKÝ, J., ENGEL, E., RATEL, J., BOUDON, A., FERLAY, A. and MARTIN, B. 2019. Forage system is the key driver of mountain milk specificity. Journal of Dairy Science, 102(11): 10483-10499.

COPPA, M., REVELLO-CHION, A., GIACCONE, D., FERLAY, A., TABACCO, E. and BORREANI, G. 2014. Comparison of near and medium infrared spectroscopy to predict fatty acid composition on fresh and thawed milk. Food Chemistry, 150: 49-57.

CORAZZIN, M., ROMANZIN, A., SEPULCRI, A., PINOSA, M., PIASENTIER, E. and BOVOLENTA, S. 2019. Fatty Acid Profiles of Cow's Milk and Cheese as Affected by Mountain Pasture Type and Concentrate Supplementation. Animals, 68(9): E68.

DE LA VARA MARTÍNEZ, J. A., HigUeRA, A. G., ESTEBAN, M. R., ASENSIO, J. R., DELGADO, M. C., BERRUGA, I. and MOLINA, A. 2018. Monitoring bulk milk quality by an integral traceability system of milk. Journal of Applied Animal Research, 46(1): 784-790.

DE ROOS, A. P. W., VAN DEN BIJGAART, H. J. C. M., HORLYK, L. and DE JONG, G. 2007. Screening for subclinical ketosis in dairy cattle by Fourier transform infrared spectrometry. Journal of Dairy Science, 90(4): 1761-1766.

FERRAND-CALMELS, M., PALHIERE, I., BROCHARD, M., LERAY, O., ASTRUC, J. M., AUREL, M. R., BARBEY, S., BOUVIER, F., BRUNSCHWIG, P., CAIllatT, H., DOUGUET, M., FAUCON-LAHALlE, F., GELE, M., THOMAS, G., TROMMENSCHLAGER, J. M. and LARROQUE, H. 2014. Prediction of fatty acid profiles in cow, ewe, and goat milk by mid-infrared spectrometry. Journal of Dairy Science, 97(1): 17-35.

FIL-IDF, 2010. New Applications of Mid Infra-Red Spectrometry for the Analysis of Milk and Milk Products. Bulletin of the IDF $N^{\circ} 447 / 2010$. International Dairy Federation.

GODIČ-TORKAR, K. and GOLC-TEGER, S. 2008. The microbiological quality of raw milk after introducing the two day's milk collecting system. Acta Agriculturae Slovenica, 92(1): 61-74.

HANUŠ, O., ROUBAL, P., ŘÍHA, J., VYLETĚLOVÁ-KLIMEŠOVÁ, M., SAMKOVÁ, E., JEDELSKÁ, R. and KOPECKÝ J. 2014. Development in indirect infra-red determination of milk acetone. Acta Universitatis Agriculturae et Silviculturae Mendelianae Brunensis, 62(5): 919-927.

HANUŠ, O., SAMKOVÁ, E., KŘÍŽOVÁ, L., HASOŇOVÁ, L. and KALA, R. 2018. The Role of Fatty Acids in Milk Fat and the Influence of Selected Farmer Factors on their Variability - A Review. Molecules, 23(7): 1636.

KLOPČIČ, M., MALOVRH, Š., GORJANC, G., KOVAČ, M. and OSTERC, J. 2003. Prediction of daily milk fat and protein content using alternating (AT) recording scheme. Czech Journal of Animal Science, 48(11): 449-458.

MANZENREITER, H., FÜRST-WALTL, B., EGGER-DANNER, C. and ZOLLITSCH, W. 2013. Zur Eignung des Gehalts an Milchinhaltsstoffen als Ketoseindikator. In: 40. Viehwirtschaftiche Fachtagung. Irdning, 18.-19. 4. 2013, pp. 9-19.

MAURICE-VAN EIJNDHOVEN, M. H. T., SOYEURT, H., DEHARENG, F. and CALUS, M. P. L. 2013. Validation of fatty acid predictions in milk using mid-infrared spectrometry across cattle breeds. Animal, 7: 348-354.

PYTLEWSKI, J., ANTKOWIAK, I., ADAMSKI, M., KUČERA. J. and SKRZYPEK, R. 2012. Factors associated with hygienic quality of bulk tank milk produced in Central Poland. Annals of Animal Science, 12(2): 227-235.

SAMKOVÁ, E., HANUŠ, O., ŠPIČKA, J., KLIMEŠOVÁ, M., HASOŇOVÁ, L., JEDELSKÁ, R., TRÁVNÍČEK, J., KOPECKÝ, J., KALA, R. and ELICH, O. 2017. Certified METHOD QJ1510336 RO1417 CM 35 Validation and recommendations for the calibration of the indirect method of infrared spectroscopy for determination the fatty acid profile of milk fat [in Czech: Certifikovaná metodika QJ1510336 RO1417 CM 35 - název: Validace a doporučení ke kalibraci nepř́mé metody infračervené spektroskopie pro stanovení profilu mastných kyselin mléčného tuku]. Jihočeská univerzita v Českých Budějovicích. Available at: http://www.vumlekarensky.cz/upload/soubory/metodiky/um_qj1510336_ro1417_ cm35.pdf [Accessed: 2019, November 15].

SAMKOVÁ, E., KOUBOVÁ, J., HASOŇOVÁ, L., HANUŠ, O., KALA, R., KVÁČ, M., PELIKÁNOVÁ, T. and ŠPIČKA, J. 2018. Joint effects of breed, parity, month of lactation, and cow individuality on the milk fatty acids composition. Mljekarstvo / Journal for Dairy Production and Processing Improvement, 68(2): 98-107.

SAMKOVÁ, E., PEŠEK, M., HANUŠ, O., ŠLACHTA, M., ŠPIČKA, J., FRELICH, J., KOPECKÝ. J. and JEDELSKÁ, R. 2011. Zastoupení významných mastných kyselin v mléčném tuku dojnic v období pastvy. Náš chov, 71(11): 68-70.

SOJKOVÁ, K., HANUŠ, O., KUČERA, J., GENČUROVÁ, V., JEDELSKÁ, R. and KOPECKÝ, J. 2009. Určení limitu přijatelnosti pro validační korelační koeficient jako parametr kvality kalibrace infračervené 
spektroskopie (MIR) při měření základního složení kravského mléka. Výzkum v chovu skotu/Cattle Research, 51(4): 50-55.

SOYEURT, H., DARDENNE, P., DEHARENG, F., LOGNAY, G., VESELKO, D., MARLIER, M., BERTOZZI, C., MAYERES, P. and GENGLER, N. 2006a. Estimating fatty acid content in cow milk using mid-infrared spectrometry. Journal of Dairy Science, 89(9): 3690-3695.

SOYEURT, H., DARDENNE, P., GILLON, A., CROQUET, C., VANDERICK, S., MAYERES, P., BERTOZZI, C. and GENGLER, N. 2006b. Variation in fatty acid contents of milk and milk fat within and across breeds. Journal of Dairy Science, 89(12): 4858-4865.

SOYEURT, H., DEHARENG, F., GENGLER, N., MCPARLAND, S., WALL, E., BERRY, D. P., COFFEY, M. and DARDENNE, P. 2011. Mid-infrared prediction of bovine milk fatty acids across multiple breeds, production systems, and countries. Journal of Dairy Science, 94(4): 1657-1667.

VAN KNEGSEL, A. T., VAN DER DRIFT, S. G., HORNEMAN, M., DE ROOS, A. P., KEMP, B. and GRAAT, E. A. 2010. Ketone body concentration in milk determined by Fourier transform infrared spectroscopy: Value for the detection of hyperketonemia in dairy cows. Journal of Dairy Science, 93(7): 3065-3069.

Contact information

Eva Samková: samkova@zf.jcu.cz Oto Hanuš: hanus.oto@seznam.cz Jiř́i Špička: spicka@zf.jcu.cz Lenka Pecová: Pecikis@seznam.cz Jan Bedrníček: bedrnj00@zf.jcu.cz Pavel Kopunecz: pavelkopunecz@seznam.cz Zdeňka Klímová: zdenka.klimova@cmsch.cz Jaroslav Kopecký: jaroslav.kopecky@email.cz 